\title{
Comparative Analysis Of Classroom Speech In Upper Level Spanish College Courses: A Social Constructivist View
}

Graziela Rondon-Pari, Ph.D., SUNY The College at Brockport, USA

\begin{abstract}
This study reflects a social constructivist theoretical framework in which the zone of proximal development (ZPD) is a central element, as two teaching approaches, communicative language teaching $(C L T)$ and explicit focus on form (FonF) are examined. Research questions include: Are CLT and explicit FonF conducive to reaching the ZPD? Is there a difference in academic achievement in Spanish between students taught with a CLT approach as opposed to an explicit FonF? What is the ratio of mother tongue versus target language used in each of the two classrooms studied?

Findings show that the ZPD can be reached through either approach with the use of the appropriate feedback techniques. In terms of academic achievement, the explicit FonF group outperformed the CLT group, but in terms of language use, CLT group engaged in a larger proportion of target language use.
\end{abstract}

Keywords: CLT; Explicit Focus on Form; Interaction Hypothesis; Social Constructivism; ZPD

\section{REVIEW OF LITERATURE}

\section{Theoretical Framework}

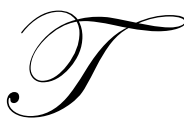

his study is based on a social constructivist theoretical framework. Constructivism in general opposes memorization and rote learning, emphasizing construction of knowledge rather than its transmission. (Gadanidis, 1994; Iran-Nejad, 1995; McDonough, 2001; Null 2004). Within the social constructivist view, Vygotsky's concept of the Zone of Proximal Development (ZPD) is at the core of the analysis. Vygotsky defined the ZPD as "the distance between the actual developmental level as determined by independent problem solving and the level of potential development as determined through problem solving under adult guidance or in collaboration with more capable peers" (Vygotsky 1978, p. 86). Given that "[language] learning is not something an individual does alone, but is a collaborative endeavor necessarily involving other individuals" (Aljaafreh \& Lantolf, 1994), it is the ZPD that constitutes the target area in every day teaching and learning.

While the ZPD made reference to first language learning, in the field of second language acquisition (SLA), we find the concept of the input hypothesis (Krashen, 1985). The input hypothesis maintains that a "condition for language acquisition to occur is that the acquirer understand (via hearing or reading) input language that contains structure a bit beyond his or her current level of competence... If an acquirer is at stage or level $i$, the input he or she understands should contain $i+1$ " (Krashen 1981, p. 100). In that sense, the input used in the classroom should be slightly above the students' current level, not too high as they would be overwhelmed, nor too low, creating conditions in which students' would not be challenged. Two important concepts for language acquisition are interaction and the use of comprehensible input (Krashen, 1985).

Krashen's work was the stepping stone to other hypotheses in SLA, among those is a social constructivist model: Long's interaction hypothesis. Krashen and Long agreed that comprehensible input promotes acquisition 
(Lightbown \& Spada, 2006). "Taking up where in a sense Krashen left off Long posits, in what has come to be called the interaction hypothesis, that comprehensible input is the result of modified interaction" (Brown 2000, p. 287). In the SLA literature, modified interaction also received the name of negotiation of meaning (De la Fuente, 2002; Naughton, 2006; Savignon, 1991). De la Fuente coincides with Long that negotiation of meaning is a crucial element in SLA. According to De la Fuente (2002) "Negotiation is usually defined as conversational modifications or adjustments that take place in communicative interactions between a native (NS) and nonnative (NNS) and also between nonnative speakers" (p. 82). At the same time Pica (1996) explains:

Throughout the research which has been carried out on negotiation, it [negotiation of meaning] has been viewed as an activity through which $L 2$ learners and interlocutors work together linguistically to repair or resolve impasses in communication and come to an understanding of each other's message meaning (p. 2).

An advantage of negotiation of meaning is that it allows students to follow a conversation without having to understand every single word. As Wong-Fillmore (1985) asserts:

Language learning occurs when students try to figure out what their teachers and classmates are saying, when teachers, through their efforts to communicate with learners, provide them with enough extra linguistic cues to allow them to figure out what is being said, and when the situation is one that allows learners to make astute guesses at the meaning of the language. (p. 35)

During negotiation what takes place in the classroom is: "participants work together to arrive at message comprehension using resources such as comprehension checks, confirmation requests, clarification requests, and so forth" (De la Fuente 2002, p. 83). Another reason why negotiation of meaning is important is because it not only enhances understanding, but also enhances the possibility of L2 production, or in other words, output.

As De la Fuente (2002) explains, "Negotiation can promote acquisition because it allows learners to understand words and structures beyond their present level of competence and, eventually, to incorporate them into their L2 production" (p. 83). The delivery of comprehensible input, as well as effort on the part of the learner to try to understand what is being said, as two important factors in the learning of a second language that can also lead to input's counterpart, output.

At the same time, negotiation of meaning is an especially important component in reaching the ZPD, because it involves dialogue, in which a more capable person, being either the teacher or another student, helps to overcome the communicative impass. As Aljaafreh and Lantolf (1994) explain, "Without dialogic negotiation, it is virtually impossible to discover the novice's ZPD" (p. 468). Also, "[second language] learning is not something an individual does alone, but is a collaborative endeavor necessarily involving other individuals" (Aljaafreh \& Lantolf 2011, p. 480). In the end, "cognitive development has its genesis in social interaction" (Anton 1999, p. 315).

The importance of communication as the focus of instruction became the key element in SLA teaching since the seventies (Horwitz, 2008) and from the many teaching approaches that favor communication, communicative language teaching (CLT) and focus on form (FonF) became popular. Nevertheless, these two approaches hold different positions on other issues.

\section{Communicative Language Teaching}

CLT classes make emphasis on the use of authentic communication by engaging in here-and-now topics by the use of group work (Horwitz, 2008), generally favoring fluency rather than accuracy (Lightbown \& Spada, 2006).

Based on the importance of negotiation of meaning, Savignon (1972) coined the phrase "communicative competence", in reference to "...the ability of language learners to interact with other speakers, to make meaning, as distinct from their ability to perform on discrete-point tests of grammatical knowledge" (Savignon 1991, p. 264). Communicative competence, a leading principle of CLT, started as a reaction to previous methods that emphasized the explicit teaching of grammar in isolation from communication, such as the Audiolingual Language Method (Savignon, 1991). In order to foster communicative competence, teachers encouraged "students to ask for 
information, to seek clarification, to use circumlocution and whatever other linguistic and nonlinguistic resources they could muster to negotiate meaning..." (Savignon 1991, p. 264). Another way of fostering communication is by engaging students in small group activities that favor a learner-centered as opposed to teacher-centered classroom (Naughton, 2006).

When communicating in a foreign language, errors are expected. When errors arise in CLT classrooms, only those errors that interfere with comprehension are addressed, while explicit grammar teaching is deemphasized, although not totally eradicated, but given secondary importance when errors do not interfere with the comprehension of the utterance (Horwitz, 2008). In that sense,

Errors were seen as a natural part of language acquisition, and they were expected to work themselves out eventually, if learners remained motivated and if they continued to have access to sufficient comprehensible input and/or opportunities for communicative interaction (Lightbown 1998, p. 190).

Learning in CLT classrooms as a whole was seen as been incidental rather than intentional (Long, 2007). Nevertheless, research started to show that some grammatical features were not acquired at target-like level from positive input and negotiation of meaning alone (Long, Inagaki \& Ortega, 1998; Schmidt, 1990; Doughty \& Williams, 1998; White, 1991). Research by Schmidt (1990, 1995, 2001) made evident that noticing, rather than input alone is the key element for acquisition to take place. He proposed the "noticing hypothesis" that stated that "noticing requires of the learner a conscious apprehension and awareness of input..." (p. 26). For Schmidt language acquisition happened in a purposeful rather than incidental form. If learners are to notice features, then more purposeful error correction, also known as negative feedback (Long, Inagaki \& Ortega, 1998), negative evidence (Morgan, Bonamo and Travis, 1995) or corrective feedback (Kubota, 1991; Lightbown \& Spada, 1990; Lyster \& Ranta, 1997), was necessary. As Long, Inagaki and Ortega (1998) asserted, "exposure to comprehensible samples of target language is necessary for acquisition but insufficient if learners are older children or adults and native-like proficiency is the goal" (p. 357). This new information created the climate for a new approach, focus on form.

\section{Focus on Form}

While focus on form (FonF) takes meaning and communication into consideration before form, Long and Robinson, (1998) explain that "during an otherwise meaning-focused classroom lesson, focus on form consists of an occasional shift of attention to linguistic code features - by the teacher and/or one or more students - triggered by perceived problems with comprehension or production" (Long and Robinson 1998, p 23). Since the advent of focus on form "A growing number of researchers have reported intentional learning to be more efficient (e.g., to occur faster) than incidental learning" (Long 2007, pp. 17-18).

FonF can be put into practice either in an implicit or explicit fashion. Implicit FonF is unobtrusive and almost imperceptible (Doughty and Williams, 1998). The explicit way is more obtrusive. Long (1991) further argues that FonF speeds up the rate of learning while improving accuracy. From then on, many articles, (e.g., Arteaga, Herschensohn \& Gess, 2003; De la Fuente, 2002; Ellis, 1994; Harley, 1992; Herschensohn, 1990; Long \& Robinson, 1998; Norris \& Ortega, 2000; Schulz, 1996; Spada, 1997) and also books (e.g., Doughty \& Williams, 1998; Lee \& Valdman, 2000) have centered on focus on form as their topic of research.

\section{RATIONALE FOR THE STUDY}

The need for studies such as the one carried out here arises from the fact that "in a global community, foreign language is a necessity, not a luxury" (Nugent 2000, p. 35). Further, nowadays many universities in the United States require students to take courses in a foreign language. Results in the learning of foreign language at the college level are not satisfactory, as explained by Carroll (1967) in a study that included 2,782 seniors majoring in foreign languages at 203 institutions: "The median graduate with a foreign language major can speak and comprehend the language only at about an FSI [Foreign Service Institute] speaking rating of ' $2+$ ', [out of 5 points] that is, somewhere between a 'limited working proficiency' and a 'minimum professional proficiency" (p. 134). Two decades later Polio and Duff (1994) noted this same problem, "if communicative competence is the goal of university FL [foreign language] programs (i.e., those that explicitly seek to teach all four skills), very few students- 
and not even graduates who have majored in FLs-are reportedly attaining levels beyond 1 or 2 on the United States Foreign Service interview scale, whose highest level is 5" (p. 313). Spanish is a very popular foreign language taught in the United States.

Spanish today is the most widely taught foreign language on American college campuses, with enrollments at some institutions surpassing the combined number of students in the next-largest fields of French, German, Italian, American Sign Language, Japanese, Chinese, and Latin. (Stavans 2005, p. 6)

For these reasons, it is important to know which type of teaching technique used by the instructor produces better results among the mostly young adult population that attends college. At the same time, more plentiful and current data on performance in Spanish among college students is needed.

This is essentially a qualitative study, although it incorporates the measurement of the occurrence of Spanish versus English discourse. As Reckard and Cook (1979) explained, quantitative and qualitative research methodologies are mutually dependent. About this same issue Chaudron (1988) said "Almost every ethnographic or discourse analytical study refers to the frequency, magnitude, or proportion of occurrences of analytical units observed (e.g., a speech act, or a type of participant structure)" (p. 15). Finally, more plentiful research comparing both SLA teaching approaches is needed. As Lightbown and Spada (2006) stated:

... it is difficult to test the hypothesis that a primary emphasis on form in the early stages of second language learning will, in the long run, lead to better results than those achieved when the primary emphasis is on meaning in the early stages. To test that hypothesis, it would be necessary to compare groups that are similar in all respect except for the type of instruction they receive (p. 141).

At the same time, the study searches for answers to the following questions: Is there a difference in academic achievement in Spanish between students taught with a CLT as opposed to an explicit FonF focus? Are CLT and explicit FonF conducive to reaching the ZPD? What is the ratio of mother tongue versus target language used by the teacher and students in each of the two classrooms studied?

\section{METHODOLOGY}

\section{Participants}

The participants were two female, instructors teaching each one section of a three hundred level Spanish class.

The first instructor was born in Central America and came to the United States in the early nineties to pursue higher education. She received a bachelor's degree and a master's degree in Spanish in a large state university in the west coast. Later on she obtained a Ph.D. In Spanish at a large public university in the Northeast. At the time of this study it was her fourth semester as an assistant professor at this institution.

The second instructor was originally from the United States. She started studying Spanish in high school, continued studying the language in her undergraduate and graduate studies and has visited Spain several times. She had over twenty years experience teaching the language at all levels, graduate and undergraduate.

Student participants consisted of two sections of a three hundred level Spanish college class. There were 20 students in each section, which was the limit imposed at this institution. Students' age ranged from 18 to 25; they were native speakers of English.

\section{RESEARCHER ROLE}

As the investigator, I conducted the instructors' and students' interviews, conducted and recorded the class observations, created the tests and the student survey. I am a native speaker of Spanish and graduate student in the Foreign and Second Language Education program, and I have taught Spanish for several years at all levels of 
undergraduate education. As an instructor of this class myself, at a different institution, I have often wondered whether the CLT or explicit FonF approaches would render different results when taught under otherwise similar conditions.

\section{MEANS OF DATA COLLECTION}

\section{Classroom Observation}

Classroom observations were undertaken by the researcher only and on a biweekly basis; there were a total of five observations in each class over the twelve-week period of the study. One of the reasons for using observation as an instrument coincides with Day's (1990) view that "the general goal of a qualitative approach is to provide rich, descriptive data about what happens in the second language classroom" (p. 44), being the research in situ an excellent source of accurate data. At the same time, the researcher wanted to confirm that each instructor was teaching and correcting students in the modality they were asked to use, namely, an implicit or explicit approach.

During the observations in each class, the researcher became a non-participant observer, which meant that there was "no involvement with the people or activities studied" (Spradley 1980, p. 59).

\section{Instructors' interview}

Instructors were interviewed based on Seidman's (1998) guidelines for in-depth phenomenological interviewing. The interviews combined "life-history interviewing and focused, in depth interviewing informed by assumptions drawn from phenomenology" (p. 9).

The interviews had as objectives to find the reasons for their choice of teaching approach and their experience in using their chosen approach. The interviews lasted approximately 20 minutes and were obtained during the first week of the study.

\section{Student Survey}

The main purpose of including a survey was to use it as a means of triangulation of data, by obtaining different sources to determine whether the instructor provided the correspondent type of error correction when the researcher was not present in the classroom. This survey includes students' opinions on how they would like to be corrected and also their opinions on how much Spanish and English they would like to be spoken in class.

\section{Tests}

For the purpose of this study, there was a pre and post-test, each with an oral and written section. The selection of materials for the tests was based on several assumptions. Some elements seem to be necessary in order for appropriate writing in a foreign language: vocabulary, grammatical knowledge and orthography (Grabe \& Kaplan, 1996). Also, Laufer and Nelson (1995) concluded that vocabulary size and composition rating are highly intercorrelated, while limited lexical resources reduce writers' possibilities to express ideas. At the same time,

Writers' ideas are not just expressed in single words but need to be cast in grammatical structures that indicate the relationships between the constituents in the clauses containing these single words. Consequently, writers need to have some grammatical knowledge at their disposal. (Schoonen et al., 2003).

Considering these ideas, it was decided that in order to evaluate the students' writing skills it was necessary to measure vocabulary, fluency of ideas expressed in writing, as well as grammatical accuracy. From these concepts the researcher determined the areas of grammar, vocabulary and fluency to be the most important areas for both the speaking and writing test sections of the pre and post-tests. Figure 1 provides a visual display of the parts of the pre and post-written tests. 


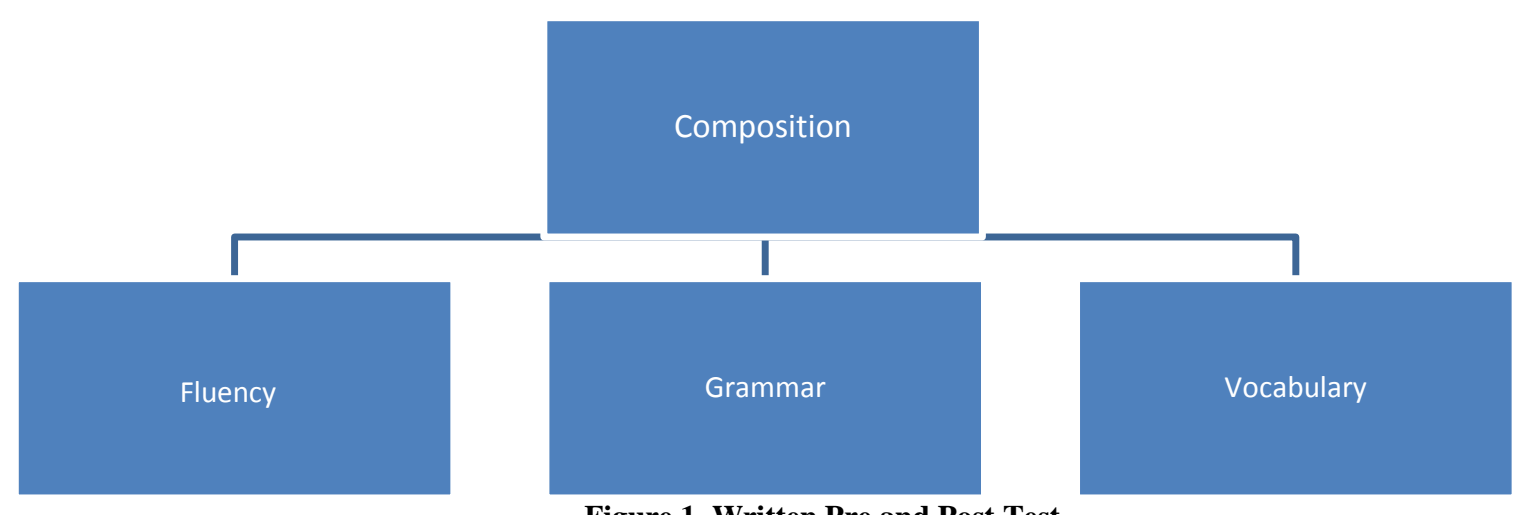

Figure 1. Written Pre and Post Test

The written test was a composition. The composition was evaluated taking into account three areas: fluency, grammar accuracy and vocabulary. Fluency of writing was evaluated by the use of connectors that facilitated a smooth transition between sentences, such as "por ejemplo" [for example], "sin embargo" [nevertheless], etc. The pre-test composition consisted on a 150-170 word self biography. The post-test composition had the following instructions: "You are being interviewed for a position you applied for, which is the ideal job for you. Tell the interviewer a little about yourself, your past, what are you doing in the present time regarding your career and what your goals for the future are. Also, the interviewer would like to know, if you were hired immediately what changes would you make to improve the company. Write a composition containing between 180 and 200 words".

The oral test, on the other hand, was an oral interview, also evaluated in terms of fluency, grammar and vocabulary. Figure 2 shows the elements of the oral interview, which were the same for the pre and post-test.

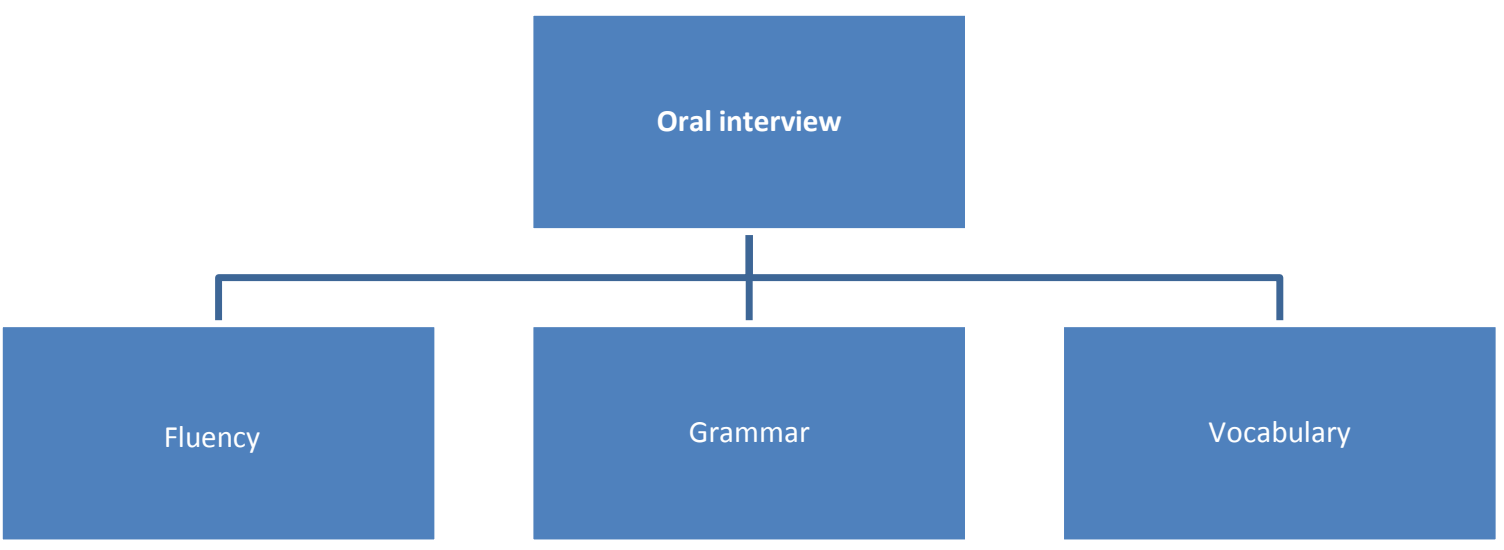

Figure 2. Oral Interview for Pre and Post-Test

The pre and a post oral test consisted on a tape recorded interview with each of the students. The pre-test interview consisted on general questions, such as their names, age, place of origin, family and regarding things they liked and disliked from their college. The post-test interview was based on open ended questions regarding the student's present, past, and future, as well as goals and "if clauses" that require the students to use a variety of grammatical and vocabulary knowledge. The interviews lasted approximately 8-10 minutes each and were scheduled individually. 


\section{DATA ANALYSIS}

Students in each group received different feedback. In the case of the CLT group, errors were only addressed when they interfered with communication, whereas the explicit FonF group addressed errors that were deemed to be remediable and seemed to have become a pattern. CLT group followed body language and sounds as well as clarification requests and recast as forms of feedback. The explicit FonF group followed elicitation of correct forms, explicit corrections and metalinguistic feedback. All forms of error correction were adopted from (Lyster \& Ranta's 1997) types of feedback.

\section{Body language and sounds}

Implicit error correction could be put into action by using body language or sounds, in which the instructor by frowning, gestures or hand movements indicated that something was not correct. This third type also included sounds, such as "hmm". In these last two types, students were made aware that there was an incorrect utterance, but they themselves were supposed to correct the mistake. An example of this category was found during the third observed class:

Student 1: "Ayer no comí porque no tengo hombre"

Teacher: “Uhm?”

Student 2: "No tenía hambre"

Student 1: "No tenía hambre"

[Yesterday I did note at because I don't have man]

[I wasn't hungry].

[I wasn't hungry].

\section{Clarification requests}

This type of error correction may indicate that the utterance has not been understood. A clarification request may include phrases such as: "Pardon me" and it may also include a repetition of the error as in "what do you mean by X?" (Lyster \& Ranta 1997).

\section{Recast}

This type of implicit form of error correction, called "recast" by Lyster \& Ranta (1997) and "paraphrase" by Spada and Fröhlich (1995), would take place when the teacher repeats the student's utterance minus the wrong part. For example:

Student: "He write books."

Teacher: "He writes books. What else does he do?"

\section{Elicitation}

In this type of error correction the teacher tries to elicit, or in other words to bring out, the correct form from the student instead of providing the answer once the error took place. Elicitation includes three types of techniques: First, a completion of a phrase to allow the student to "fill in the blank." This first type of elicitation would include phrases such as: "No, not that. It's a ..." Second, it may also include questions for the students to be able to repair the error themselves: "How do we say X in Spanish?" This second type of elicitation does not include yes/no answers, which would fall into a metalinguistic feedback: "Do we say X in Spanish?" And finally, it may also be a request for the student to reformulate the utterance: "say it again." (Lyster \& Ranta, 1997)

\section{Explicit correction}

"Explicit correction refers to the explicit provision of the correct form. As the teacher provides the correct form, he or she clearly indicates that what the student had said was incorrect (e.g., 'Oh, you mean', 'you should say')" (Lyster \& Ranta 1997, p. 46). 


\section{Metalinguistic feedback}

This form of error correction consists of comments, questions or requests for information in order for the student to repair the error. "Metalinguistic information generally provides either some grammatical metalanguage that refers to the nature of the error (e.g., 'it's masculine') or a definition in the case of lexical errors" (Lyster \& Ranta 1997, p. 47).

\section{RESULTS}

\section{Research question 1: Are CLT and explicit FonF conducive to reaching the ZPD?}

The observation of error correction in both classes allowed the experience to see how two forms of error correction can lead into constructivist friendly classrooms. The CLT group, by the use of implicit error correction fits well with the constructivist theory; the instructor does not interrupt students' speech and through the use of body language, gestures and sounds allowed students to let them know that an error took place. Implicit error correction also allowed to either self correct or for other students to provide the answer, an ideal situation for a more capable peer to guide the classmates into the zone of proximal development (ZPD). Curiously, the explicit FonF group was also capable to arrive at the right answer through the collaboration of peers. Such was the case of two types of explicit correction used in the FonF group: Elicitation and metalinguistic correction. These two forms of error correction allowed students to self correct also were well received by students, according to the instructor's interview and to the researcher's field notes. From the analysis and observations, it became clear that rather than one error correction type, an eclectic style, incorporating body language and sounds to let students note an error, as well as the use of elicitation and metaliguistic correction, allow for constructivist like settings that favor the ZPD to be reached by students themselves. In this way, it allows for a student-centered classroom with plenty of comprehensible input and output, mediated by negotiation of meaning when the occasion calls for it.

\section{Research question \#2: Is there a difference in academic achievement in Spanish between students taught with a CLT approach as opposed to an explicit FonF?}

In general terms, the explicit FonF group, outperformed the CLT group in the post test. As we see in Appendix A, the CLT group performed at an average of 74 points in the composition and 72.7 in the interview (Appendix A), as opposed to75.8 and 73.7 in the FonF group (Appendix B). The difference in the post-tests is nonstatistically significant at the 0.5 margin of error, which means that we cannot assume with $95 \%$ of certainty that the difference between the mean scores obtained by each group in the post-tests is due to actual better performance from the part of the explicit FonF group rather than a mere chance occurrence.

The explicit FonF group had better scores in both, the oral and written post-test, which is surprising in the case of the oral test, since the CLT group engaged in more conversation and suffered less interruptions from the part of the instructor. Due to this difference in teaching, the CLT group was expected to perform better on the oral test, but this scenario did not take place. The difference between both groups was more noticeable on the composition, in which the FonF group outperformed their CLT counterparts. Some of the possible explanations for the FonF success can be explained by type of error correction used. the importance of error awareness, the clarity of explicit correction and the possible lack of student awareness when using recast.

\section{The importance of error awareness}

The two classes differed basically in the noticing or awareness of the mistakes taking place. The CLT group was exposed to less noticeable, more subtle error correction, especially when recast took place. The explicit group received a more obvious and forceful type of error correction that often required the students to self correct. This observance coincides with Hendrickson (1978), who noted that "When students are not able to recognize their own errors, they need the assistance of someone more proficient in the language than they are" (p. 389). This type of help, which is also consistent with the ZPD to enter into action, is usually carried out by the instructor or another student. Several years later, Allwright and Bailey (1991) observed that "one way of viewing instruction is that it is the teacher's job to help students move along the interlanguage continuum" (p. 91). According to these two 
researchers, this task would take place by teaching what students need to learn and also by "pointing out where their production differs from the target language model" (p. 92).

In the case of our students, it was the explicit FonF group that was more closely exposed to these two conditions mentioned by Allwright and Bailey. This important factor of the awareness of the mistake seems to have played a role in the performance of the explicit group from pre to post test on one measure, the composition.

\section{Explicit Correction}

Most students in the explicit FonF group were in agreement with the use of explicit error correction.

In the explicit group it is worth noting that error correction forced the student to notice the mistakes and it usually forced the student to either acknowledge them, by repeating the correct form, or by repairing the mistakes themselves.

The most common forms of explicit correction, after the explicit style itself, were the metalinguistic and elicitation forms. On the other hand, metalinguistic and elicitation were two forms of error correction that appeared often and those two forms were prone to student self repair, with the aid of clues given by the instructor. Lyster and Ranta (1997), Lyster (2001) also Sanz and Morgan-Short (2005) also found favorable results with the elicitation and metalinguistic forms. These two researchers found that both elicitation and metalinguistic error correction are conducive to student self correction and negotiation of form. The same situation took place in the explicit FonF classes observed for this study; an excerpt from the last observed class illustrates this issue:

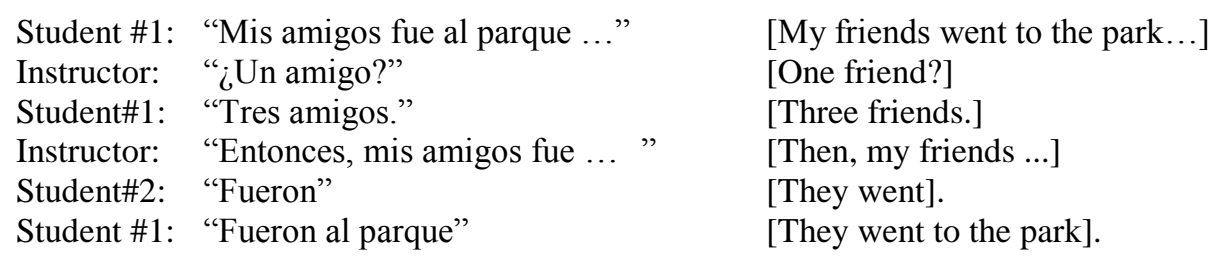

Noticing the mistakes and giving clues allow the students to find the right form, in this case with the aid of the instructor and another student serving the purpose of "a more capable peer", when referring to the Zone of Proximal Development (ZPD). The help of both, instructor and a peer, allowed the student to arrive at the correct form of expressing his idea.

Other studies support the idea of explicit correction being a more efficient way of error correction over the implicit form. Among such studies is one carried out by Carroll and Swain (1993), who found that the explicit metalinguistic group outperformed all the other groups, including the recast group. Later on Spada (1997) concluded in her research study that the explicit group was more effective in communicatively and content based classes. Also, in 2002, Mulryan found explicit correction to provide slightly better results than implicit corrections in short term and long term post-tests when learning the verbs "ser" and "estar".

\section{Recast: Possible Lack of Error Awareness}

In the case of the CLT group, on the other hand, according to the student survey and the class observations, correction occurred by means of recast and body language or sounds. Recast, "the teacher's reformulation of all or part of a student's utterance minus the error" (Lyster \& Ranta, 1997, p. 46), was the perceived form of error correction used in class, while body language and/or sounds were used in a lesser extent.

When using recast, the reaction observed on the part of the students was that most of the time the student continued speaking after the teacher's correction, without acknowledging the error and there was no repetition of the correct form, modeled by the instructor, as in the following excerpt: 
Student: “... porque [yo] está en la escuela ...” [Because I is in school].

Instructor: "Porque [yo] estoy en la escuela." [Because I am in school].

Student: "Yo trabajo mucho para tener dinero." [I work much to have money].

In this example, without the student repeating the right utterance it is not possible to know whether she realized that she was being corrected and, in the event she knew that she was being corrected, she may not have paid attention to the correction, because of the fact that she was trying to put together what she was going to say next. For the rest of the students, too, unless they were closely following the conversation, they might not have noticed the correction. With the use of recast, students may confuse the correction with either a repetition of the student's utterance, from the part of the instructor, or an exact paraphrase of the student's speech to confirm the teacher's attention to the speech.

Noticing the error is an important issue in second language acquisition, as explained by Schmidt (1990): "noticing is the necessary and sufficient condition for converting input to intake" (p. 129), in other words, for what is being heard in class to become readily available knowledge.

These findings of the disadvantage of recast as means of noticing the error were also in accordance with previous studies, such as Allbright and Bailey (1991), who explained that foreign and second language learners should have "both time and opportunity ... for self-repair, whether it is self -or other - initiated" (p. 107). Later on Lyster (2001) found recast to be ineffective in promoting self repair, and negotiation of meaning.

\section{Sounds and Body Language: Self or Peer Correction}

The second type of implicit error used in the CLT group provided a different reaction on the part of the students. With body language and/or sounds as means of letting students know that an utterance was not understood and it was completely up to the students to find the right form. These two types of error correction were observed especially during group and pair work when the teacher passed by each group.

This type of error awareness, by the use of a sound, seemed to be a low threat and an amusing experience to the students. The instructor, a person from Latin America, was expressive and lively, and used sounds and gestures with a natural and friendly demeanor. This same type of feedback was noted to be a successful tool by McCafferty (2002), who stated that the use of gesture "support a view of the ZPD as revolutionary activity" (p. 200).

The use of sound in the example mentioned here not only allowed any student in the group the possibility of providing the correct answer, but also allowed the students themselves to self correct, without the use of clues, as was the case in the metalinguistic and elicitation type of explicit correction.

\section{Research question \#3: What is the ratio of mother tongue versus target language used in each of the two classrooms studied?}

In order to measure the use of each language, taped recorded classes were transcribed verbatim and later analyzed. Each phrase said in class was assigned to either of the following four categories: English, Spanish, English and Spanish mixed and not understood. The total number of phrases was divided into percentages for an easier understanding. In table 1 shows that in the CLT group English was spoken 9.2\% of the time and Spanish $88.6 \%$ of the time.

Table 1: Summary CLT Language Use

\begin{tabular}{|c|c|c|c|c|c|}
\hline Session & English & Spanish & English Spanish mixed & Not understood & Total \\
\hline 1 & $8 \%$ & $89 \%$ & $3 \%$ & 0 & $100 \%$ \\
\hline 2 & $10 \%$ & $88 \%$ & $1 \%$ & $1 \%$ & $100 \%$ \\
\hline 3 & $8 \%$ & $91 \%$ & $1 \%$ & 0 & $100 \%$ \\
\hline 4 & $11 \%$ & $87 \%$ & $1 \%$ & $1 \%$ & $100 \%$ \\
\hline 5 & $9 \%$ & $88 \%$ & $2 \%$ & $1 \%$ & $100 \%$ \\
\hline Mean & $9.2 \%$ & $88.6 \%$ & $1.6 \%$ & $0.6 \%$ & $100 \%$ \\
\hline
\end{tabular}


This is a fairly high amount of English, considering that this was an upper beginning Spanish class. At the same time, there is a low frequency of alternation of languages in an utterance (1.6\%), mainly used by students when an unknown word was used, as in the following excerpt:

Student: ¿Cómo se dice I had a hunch?

[How do you say I had a hunch?]

Instructor: Tuve una corazonada. Es como pensar con el corazón. [I had a hunch. It's like thinking with the heart].

Table 2: Summary explicit FonF Language Use

\begin{tabular}{|c|c|c|c|c|c|}
\hline Session & English & Spanish & English Spanish mixed & Not understood & Total \\
\hline 1 & $22 \%$ & $70 \%$ & $4 \%$ & $4 \%$ & $100 \%$ \\
\hline 2 & $20 \%$ & $72 \%$ & $3 \%$ & $5 \%$ & $100 \%$ \\
\hline 3 & $16 \%$ & $75 \%$ & $7 \%$ & $2 \%$ & $100 \%$ \\
\hline 4 & $48 \%$ & $49 \%$ & $1 \%$ & $2 \%$ & $100 \%$ \\
\hline 5 & $22 \%$ & $70 \%$ & $3 \%$ & $5 \%$ & $100 \%$ \\
\hline Mean & $25.6 \%$ & $67.2 \%$ & $3.6 \%$ & $3.6 \%$ & $100 \%$ \\
\hline
\end{tabular}

In the explicit FonF group English accounted for $25.6 \%$ of the total number of utterances. There was also a higher use of code switching between English and Spanish (3.6\%). Three situations in which the use of English increases as opposed of the use of target language arose in the FonF group: grammar instruction, class management and conversations regarding administrational issues. We will see each aspect separately.

\section{The use of English for administrational issues}

The most frequent use of English from the part of the instructor took place when talking about the syllabus, evaluations and other administrational topics. Some words, such as "syllabus", "exam", "quiz" and "vocabulary" were frequently used, as denoted in the following excerpt from the third tape-recorded session:

Teacher: "So, tell me, when is the quiz going to take place?"

Students: "Friday"

Teacher: "Remember to review the vocabulary on page 251, this is also going to be part of the final exam."

Student: "Do you know when is the final?"

Teacher: "Not yet. They haven't announced the date yet."

This dialogue took place entirely in English, even though students already knew the pertinent vocabulary and the tenses used. The use of target language for this dialogue could have taken place in Spanish, and if not fully understood, negotiation of meaning would have helped.

As a possible argument to explain the lack of target language use in this type of situation is that the instructor may not consider this to be part of the lesson. During the interview with the instructor. She expressed: "Sometimes I speak English to make announcements, because that is not part of the lesson to be covered that day."

The scarce time available in class could have been used for instructing in the target language, especially because these administrative announcements took place every day this study was conducted and because the specifics of these evaluations, such as dates, were contained in the syllabus. In this case if not fully understood students could ask for clarification and negotiation of meaning could be used.

\section{The use of English for grammar instruction}

The second function for which the teacher used more English than the target language was in grammar instruction. We see an increase in the use of English in the first three sessions, which took place before the test. After the test there was a decrease in its use. 
Given that grammar constitutes part of the lesson, as opposed to the previous factor, according to the instructor, one might expect an increased use of Spanish, but once again English was used as a medium of communication. At the interview, the instructor said:

Whenever possible I speak Spanish to teach grammar concepts, to practice and review them, but once in a while, when it is a difficult point or when a test is coming up, like last week, I have to speak English to make sure that the students understand, because that's why I am in the classroom, to clarify things and to make sure they understand. But when it is a normal day I use Spanish almost all the time.

As expressed by the instructor, the amount of English spoken in reference to grammar the days before the test actually increased and after the test it decreased, but not to the point to be "Spanish almost all the time" as expressed by her.

\section{Use of English for classroom management}

Under this category lie expressions such as: please, next, thank you, come to the chalkboard, open your book/notebook, page number, and so on. These phrases were learnt in the previous two semesters and were repeated continuously almost every class. Students seemed not to have problems understanding these phrases and obeyed for the most part. However, when using those phrases students usually spoke English, as exemplified in a dialogue that took place on the second session:

Teacher: "Frank, do you know the answer? Escríbela en la pizarra." (Write it down on the chalkboard)

Pam: "Should I write it on the chalkboard?"

Teacher: "Yes"

In this case the student seemed not to have heard the teacher. The student could have asked for clarification in Spanish, but instead spoke English without been corrected by the teacher. It seems that using English is a habit more than a necessity.

\section{CONCLUSION}

Based on the observations and field notes, it was possible to determine that both, CLT and explicit FonF allowed for a "more capable peer" intervention to reach the zone of proximal development. The types of error correction that allowed peer help and were conducive to the ZPD in the CLT group were the use of body language and sounds, but not recast, given that recast left no room for self or peer correction. In the explicit FonF group, the types of error correction that were conducive to the ZPD were metalinguistic and elicitation types of explicit correction. At the same time, the type of error correction that was conducive to constructivist learning was not exclusively the implicit approach, but rather varied according to the specific error correction form within the explicit or implicit approach. In the explicit FonF group, it was found that the use of elicitation and metalinguistic feedback not only allowed for the ZPD to be reached, but also allowed classmates to be active participants in reaching it, by allowing more capable peers in class instruction and group work to correct their peers. In the CLT group, on the other hand, the use of body language and sounds as means of the instructor making students aware of their mistakes provided the opportunity for students to self correct or other classmates to provide the right answer and, in that way, make it possible to arrive to the ZPD in collaboration of peers.

In general terms, both classes showed progress in their oral and written performance in the Spanish language. The explicit FonF group demonstrated a higher increase of achievement and scores in both tests, but the difference was not statistically significant. This difference in achievement may be due to the fact that the explicit FonF group was more aware of their mistakes than the CLT group. This finding is consistent with Norris and Ortega's (2000) conclusion that explicit types of instruction are more effective than implicit ones. A larger difference than between group results was found within each of the two groups, from the pre to the post-tests in the performance of students on the tests. 
In regards to target language use, Spanish was spoken at a higher rate in the CLT group. The instances that prompted a higher use of the English language in the explicit FonF group fell into three categories: administrative issues, grammar explanations and classroom management.

It is important to create awareness on the language used in order to avoid resorting to the mother tongue when addressing these categories.

Three key areas of foreign language teaching that have been of common interest in the history of foreign language education were explored: social constructivist learning through communicatively oriented classrooms, error correction and English versus target language speech that took place in the classrooms studied. From a pedagogical point of view, the author hopes to provide light on the importance of using methods that enable foreign language students to reach the ZPD through social interaction and the help of peers in order to allow for student centered classrooms.

\section{AUTHOR INFORMATION}

Graziela Rondon-Pari, Ph.D.Assistant Professor of Spanish at SUNY Brockport. Received Ph.D. in Second and Foreign Language Education from the University at Buffalo in 2006. She specializes in foreign language proficiency and is a certified Oral Proficiency Rater with the American Council of the Teaching of Foreign Languages (ACTFL). E-mail: grondonp@ brockport.edu

\section{REFERENCES}

1. Allbright, D., \& Bailey, K. (1991). Focus on the Language Classroom. Cambridge, UK: Cambridge University Press.

2. Anton, M. (1999). The discourse of a learner-centered classroom: Sociocultural perspectives on teacherlearner interaction in the second-language classroom. The Modern Language Journal, 83(3), 303-318.

3. Arteaga, D., Herschensohn, J., \& Gess, R. (2003). Focusing on phonology to teach morphological form in French. The Modern Language Journal, 87, 58-70.

4. Aljaafreh, A., \& Lantolf, J. (1994). Negative feedback as regulation and second language learning in the zone of proximal development. The Modern Language Journal, 78 (4), 465-483.

5. Brown, H. D. (2000). Principles of Language Learning and Teaching. New York: Longman.

6. Carroll, J. (1967). The foreign language attainments of language majors in the senior year. Foreign Language Annals, 12, 131-152.

7. Carroll, S., \& Swain, M. (1993). Explicit and implicit negative feedback: An empirical study of the learning of linguistic generalizations. Studies in Second Language Acquisition, 15, 357-386.

8. Chaudron, C. (1988). Second Language Classrooms. Research on Teaching and Learning. New York: Press Syndicate of the University of Cambridge.

9. Day, R. (1990). "Teacher observation in second language teacher education". In J. Richards and D. Nunan, (Eds). Second Language Teacher Education. Cambridge, UK: Cambridge University Press.

10. De la Fuente, M. J. (2002). Negotiation and oral acquisition of L2 vocabulary: The roles of input and output in the receptive and productive acquisition of words. Studies in Second Language Acquisition, 24, $81-112$.

11. Doughty, C. \& Williams, J. (1998). Pedagogical choices in focus on form. In C. Doughty and W. Williams (pp. 197-285). Focus on Form in Classroom Second Language Acquisition. Cambridge, England: Cambridge University Press

12. Ellis, R. (1994). The Study of Second Language Acquisition. Oxford: Oxford University Press.

13. Gadanidis, G. (1994). Deconstructing constructivism. Mathematics Teacher, 87(2), 91-97.

14. Grabe, W., \& Kaplan, R. (1996). Theory and practice of writing. New York: Longman.

15. Harley, B. (1992). Patterns of second language development in French immersion. Journal of French Language Studies, 10 (3), 331-359.

16. Hendrickson, J. (1978). Error correction in foreign language teaching: Recent theory, research and practice. The Modern Language Journal, 62, 387-398. 
17. Herschenson, J. (1990). Toward a theoretical basis for current language pedagogy. The Modern Language Journal, 74, 451-458.

18. Horwitz, E. K. (2008). Becoming a Language Teacher. A Ractical Guide to Second Language Learning and Teaching. Boston: Pearson.

19. Iran-Nejad, A. (1995). Constructivism as substitute for memorization in learning: Meaning is created by learner. Education, 116(1), 16-31.

20. Krashen, S. (1981). Second Language Acquisition and Second Language Learning. Oxford: Pergamon Press.

21. Krashen, S. (1985). The Input Hypothesis: Issues and Implications. London: Longman.

22. Kubota, M. (1991). Corrective feedback by experienced Japanese EFL teachers. Institute for Research in Language Teaching Bulletin, 5, 1-25. ED 386002.

23. Laufer, B., \& Nelson, P. (1995). Vocabulary size and use: Lexical richness in L2 written production. Applied Linguistics, 16(3), 307-322.

24. Lee, J., \& Valdman, A. (2000). Form and Meaning. Multiple Perspectives. Boston, MA: Heinle \& Heinle.

25. Lightbown, P. (1998). The importance of timing in focus on form. In C. Doughty and J. Williams (Eds.). Focus on Form in Classroom Second Language Acquisition (pp. 177-196). Cambridge, UK: University Press.

26. Lightbown, P. M., \& Spada, N. (1990). Focus on Form and Corrective feedback in communicative language teaching: Effects on second language learning. Studies in Second Language Acquisition, 12(4), 429-48.

27. Lightbown, P. M., \& Spada, N. (2006). How Languages Are Learned. Oxford: Oxford University Press.

28. Long M. (1991). Focus on form: A design feature in language teaching methodology. In K. de Bot, R. B. Ginsberg, \& C. Kramsck (Eds.). Foreign Language Research in Cross-cultural Perspective (pp. 39-52). Amsterdam: Benjamins.

29. Long, M. (2007). Problems in SLA. New York: Lawrence Erlbaum Associates.

30. Long, M., Inagaki, S., \& Ortega, L. (1998). The Role of Implicit Negative Feedback in SLA: Models and Recasts in Japanese and Spanish. The Modern Language Journal, 82(3), 357-371.

31. Long, M. H., \& Robinson, P. (1998). Focus on form: Theory, Research, and Practice. In C. Doughty and J. Williams (Eds.). Focus on Form in Classroom Second Language Acquisition. Cambridge, UK: University Press.

32. Lyster, R. (2001). Negotiation of form, recasts, and explicit correction in relation to error type and learner repair in immersion classrooms. Language Learning, 51(1), 265-301.

33. Lyster, R., \& Ranta, L. (1997). Corrective feedback and learner uptake: Negotiation of form in communicative classrooms. Studies in Second Language Acquisition, 19, 37-66.

34. McCafferty, S. (2002). Gesture and creating zones of proximal development for second language learning. The Modern Language Journal, 86(2), 192-203.

35. McDonough, S. (2001). Way beyond drill and practice: Foreign Language lab activities in support of constructivist learning. International Journal of Instructional Media, 28 (1), 75-81.

36. Morgan, J., Bonamo, K., \& Travis, L. (1995). Negative evidence on negative evidence. Developmental Psychology, 31(2), 180-197.

37. Mulryan, S. (2002). Explicit versus implicit grammar in the teaching of the ser/estar distinction in Spanish. Unpublished doctoral dissertation, University at Buffalo, New York.

38. Naughton, D. (2006). Cooperative strategy training and oral interaction: Enhancing small group communication in the language classroom. The Modern Language Journal 90(2), 169-184.

39. Norris, J. M., \& Ortega, L. (2000). Effectiveness in L2 instruction: A research synthesis and quantitative meta-analysis. Language Learning, 50, 417-528.

40. Nugent, S. (2000). Foreign language instruction in a global community. NASSP Bulletin, 84_35-40.

41. Null, W. (2004). Is constructivism traditional? Historical and practical perspectives on a popular advocacy. The Educational Forum, 68 (2), 180-188.

42. Pica, T. (1996). Do second language learners need negotiation? International Review of Applied Linguistics, 34, 1-21.

43. Polio, C., \& Duff, P. (1994). Teachers' language use in university foreign language classrooms: A qualitative analysis of English and target language alternation. The Modern Language Journal, 78, 313326. 
44. Reckard, C., \& Cook, T. D. (1979). Beyond qualitative versus quantitative methods. In T. D. Cook and C. Reickard (Eds.). Qualitative Methods in Evaluation Research. Beverly Hills, CA: Sage Publications.

45. Sanz, C., \& Morgan-Short, K. (2005). Explicitness in pedagogical interventions: Input, practice, and feedback. In C. Sanz (Ed.). Mind and Context in Adult Second Language Acquisition. Washington, DC: Georgetown University Press.

46. Savignon, S. (1972). Communicative Competence : An Experiment in Foreign Language Teaching. Philadelphia : Center for Curriculum Development.

47. Savignon, S. (1991). Communicative language teaching: State of the art. TESOL Quarterly, 25(2), $261-277$.

48. Schmidt, R. (1990). The role of consciousness in second language learners. Applied Linguistics, 11(1), 1746.

49. Schmidt, R. (1995). Consciousness and foreign language learning: A titorial on the role of attention and awareness in learning. In R. Schmidt (Ed.). Attention and Awareness in Foreign Language Learning (pp. 163). Honolulu: University of Hawai'i Press.

50. Schmidt, R. (2001). Attention. In P. Robinson (Ed.). Cognition and Second Language Instruction (pp. 332). Cambridge, England: Cambridge University Press.

51. Schoonen, R., van Gelderen, A., de Glopper, K., Hulstijn, J., Simis, A., Snellings, P., \& Stevenson, M. (2003). First language and second language writing: The role of linguistic knowledge, speed of processing, and metacognitive knowledge. Language Learning, 53(1), 165-202.

52. Schulz, R. (1996). Focus on Form in the Foreign Language Classroom: Students' and Teachers' Views on Error Correction and the Role of Grammar. Foreign Language Annals 29(3), 343-364.

53. Seidman, I. (1998). Interviewing as Qualitative Research. New York: Teachers College Press.

54. Spada, N. (1997). Form-focused instruction and second language acquisition: A review of classroom and laboratory research. Language Teaching, 30, 73-87.

55. Spradley, J. (1980). Participant Observation. Fort Worth: Harcourt Brace College Publishers.

56. Stavans, I. (2005). The challenge facing Spanish departments. The Chronicle of Higher Education, 51(47), 6-8.

57. Stevenson, M. (2003). First language and second language writing: The role of linguistic fluency, linguistic knowledge and metacognitive knowledge. Language Learning, 53(1), 165-202.

58. Vygotsky, L. S. (1978). Mind in Society: The Development of Higher Psychological Processes. In M. Cole, V. J. Steiner, S. Scribner, \& E. Souberman (Eds.). Cambridge, MA: Harvard University Press.

59. White, L. (1991). Adverb placement in second language acquisition: Some effects of positive and negative evidence in the classroom. Second Language Research, 7, 133-161.

60. Wong-Fillmore, L. (1985). When does teacher talk work as input? In S. Gass \& C. Madden (Eds.). Input in Second Language Acquisition (pp. 235-253). Rowley, MA: Newbury House. 
Contemporary Issues In Education Research - December 2011

Volume 4, Number 12

APPENDIX A: CLT Group Results

\begin{tabular}{|c|c|c|c|c|}
\hline \multirow{2}{*}{ Student } & \multicolumn{2}{|c|}{ Pre-Test } & \multicolumn{2}{c|}{ Post-test } \\
\cline { 2 - 5 } & Composition & Interview & 88 & 86 \\
\hline 1 & 84 & 81 & 67 & 60 \\
\hline 2 & 64 & 60 & 70 & 66 \\
\hline 3 & 72 & 66 & 90 & 91 \\
\hline 4 & 89 & 88 & 61 & 58 \\
\hline 5 & 55 & 48 & 93 & 95 \\
\hline 6 & 90 & 92 & 84 & 88 \\
\hline 7 & 85 & 87 & 80 & 81 \\
\hline 8 & 74 & 67 & 100 & 97 \\
\hline 9 & 98 & 95 & 56 & 50 \\
\hline 10 & 38 & 24 & 68 & 66 \\
\hline 11 & 70 & 76 & 71 & 68 \\
\hline 12 & 66 & 60 & 38 & 40 \\
\hline 13 & 28 & 35 & 76 & 77 \\
\hline 14 & 73 & 70 & 58 & 55 \\
\hline 15 & 52 & 50 & 32 & 30 \\
\hline 16 & 23 & 20 & 70 & 68 \\
\hline 17 & 77 & 71 & 95 & 94 \\
\hline 18 & 93 & 90 & 89 & 98 \\
\hline 19 & 88 & 82 & 94 & $30-97$ \\
\hline 20 & 91 & 90 & 74 & 72.7 \\
\hline Range & $23-98$ & 67.6 & & \\
\hline
\end{tabular}


Contemporary Issues In Education Research - December 2011

APPENDIX B: Explicit FonF Group Results

\begin{tabular}{|c|c|c|c|c|}
\hline \multirow{2}{*}{ Student } & \multicolumn{2}{|c|}{ Pre-Test } & \multicolumn{2}{c|}{ Post-Test } \\
\cline { 2 - 5 } & Composition & Interview & 71 & 70 \\
\hline 1 & 66 & 65 & 43 & 40 \\
\hline 2 & 31 & 25 & 76 & 75 \\
\hline 3 & 72 & 68 & 91 & 98 \\
\hline 4 & 88 & 84 & 94 & 82 \\
\hline 5 & 90 & 88 & 86 & 65 \\
\hline 6 & 82 & 80 & 62 & 82 \\
\hline 7 & 55 & 50 & 84 & 53 \\
\hline 8 & 78 & 75 & 57 & 45 \\
\hline 9 & 50 & 54 & 50 & 69 \\
\hline 10 & 38 & 40 & 68 & 88 \\
\hline 11 & 64 & 60 & 89 & 95 \\
\hline 12 & 81 & 85 & 98 & 78 \\
\hline 13 & 92 & 94 & 80 & 35 \\
\hline 14 & 75 & 75 & 32 & 69 \\
\hline 15 & 24 & 22 & 76 & 85 \\
\hline 16 & 72 & 65 & 91 & 98 \\
\hline 17 & 85 & 84 & 98 & 77 \\
\hline 18 & 95 & 94 & 76 & 98 \\
\hline 19 & 74 & 75 & 90 & 73.7 \\
\hline 20 & 86 & $22-94$ & $75-98$ & \\
\hline Range & $24-95$ & 68.4 & & \\
\hline
\end{tabular}


NOTES 